\title{
$O, N$-Chelated Vanadium(IV) Oxo Aminophenolate Complexes: the Effect of Steric Bulk on the Vanadium Coordination Geometry. Can this Influence be detected Spectroscopically?
}

\author{
Henk Hagena, Santiago Reinoso'), Ed J. Reijerse ${ }^{c}$, Ernst E. van Faassen ${ }^{\text {, }}$, Martin Lutz ${ }^{\mathrm{e}}$, Anthony L. Spek ${ }^{\mathrm{e}, 2)}$, \\ and Gerard van Koten ${ }^{\mathrm{a}, *}$ \\ Utrecht / The Netherlands, ${ }^{a}$ Debye Institute, Department of Metal-Mediated Synthesis, ${ }^{\mathrm{d}}$ Department of Atomic and Interface Physics,

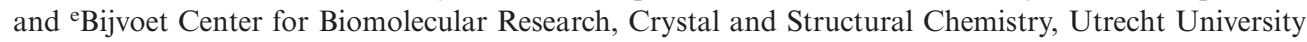

${ }^{c}$ Nijmegen / The Netherlands, Department of Molecular Spectroscopy, University of Nijmegen

Received July $30^{\text {th }}, 2004$.

Dedicated to Professor Michael Veith on the Occasion of his $60^{\text {th }}$ Birthday

\begin{abstract}
In order to study the effect of steric bulk on the vanadium coordination geometry in $O, N$-chelated vanadium oxo (bis)phenolates, six different ortho-aminophenolate ligands have been used. The ortho-aminophenolate system was changed at three different places, i.e. 1) the second ortho position $\left(\mathrm{C}^{6}\right)$ of the arene ring $(\mathrm{R})$, 2) the substituents at the amino nitrogen ( $R^{\prime}$ and $\left.R^{\prime \prime}\right)$, and 3$)$ the benzylic carbon atom $\left(\mathrm{R}^{*}\right)$. The phenols were used in the preparation of the vanadium oxo (bis)phenolate complexes. In order to study whether it is possible to predict geometrical features of
\end{abstract}

these vanadium complexes, UV/Vis, solution and frozen state EPR and ${ }^{14} \mathrm{~N}$ ESEEM spectroscopic data was measured and compared to the structural features of four structurally characterized vanadium oxo (bis)phenolates. Unfortunately, it turned out that is was not possible to correlate the EPR parameters, the UV/Vis HOMO-LUMO transitions or ${ }^{14} \mathrm{~N}$ hyperfine couplings to the structural parameters.

Keywords: Vanadium; O,N-ligands; EPR spectroscopy; UV/Vis spectroscopy; ${ }^{14} \mathrm{~N}$ ESEEM spectroscopy

\section{$O, N$-Chelat Vanadium(IV) Oxo Aminophenolat Komplexe: Der Einfluss der sterischen Hinderung auf die Vanadium Koordinationsgeometrie. Kann dieser Effekt spektroskopisch nachgewiesen werden?}

Inhaltsübersicht. Zur Untersuchung des sterischen Einflusses auf die Koordinationsverhältnisse von $O, N$-chelatisierten VanadiumOxo(bis)phenolaten wurden sechs verschiedene ortho-Aminophenolatliganden angewandt. Das ortho-Aminophenolatsystem wurde auf drei verschiedene Arten variiert: 1) an der zweiten ortho-Position $\left(\mathrm{C}^{6}\right)$ des Arenringes (R), 2) mit den Substituenten am Aminostickstoffatom ( $\mathrm{R}^{\prime}$ und $\left.\mathrm{R}^{\prime \prime}\right), 3$ ) am benzylischen Kohlenstoffatom $\left(\mathrm{R}^{*}\right)$. Die Phenole wurden zur Herstellung der Vanadium-Oxo(bis)phenolat-Komplexe eingesetzt. Um die Möglichkeiten strukturel- ler Merkmale dieser Vanadiumkomplexe vorherzusagen, wurden die UV-vis- sowie die EPR- und ${ }^{14} \mathrm{~N}$-ESEEM-Spektren in Lösung und im eingefrorenen Zustand gemessen und mit den strukturellen Merkmalen von vier strukturell charakterisierten Vanadium-Oxo(bis)phenolaten verglichen. Unglücklicherweise stellte sich heraus, daß es nicht möglich ist, die EPR-Parameter, die UV-vis-HOMOLUMO-Übergänge oder die ${ }^{14} \mathrm{~N}$-Hyperfein-Kopplungen mit den Strukturparametern zu korrelieren.

\footnotetext{
* Prof. Dr. G. van Koten

Debye Institute, Department of Metal-Mediated Synthesis

Utrecht University

Padualaan 8, $3584 \mathrm{CH}$

Utrecht / The Netherlands

E-mail: g.vankoten@chem.uu.nl

Fax: +31302523615

1) Visiting undergraduate student from Universidad del Pais Vasco, Bilbao, Spain

2) To whom correspondence pertaining to crystallographic studies should be addressed.

E-mail: a.1.spek@chem.uu.nl
}

\section{Introduction}

Recently we have set out to use vanadium as a catalyst in Ziegler-Natta polymerization of $\alpha$-olefins. As ancillary ligands we have chosen ortho-chelating aminophenolates (see Figure 1). This type of ligands has been used previously in our group in aluminium [1], iron [2], zinc [3], tungsten [4], and molybdenum [5] chemistry and they proved to be versatile in the stabilization of metal atoms in various oxidation states. Earlier we have reported that substituent variation at the meta or para positions can have a significant electronic influence on the vanadium atom [6]. 


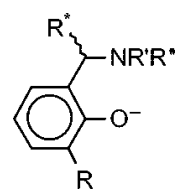

Figure 1 Selected ortho-aminophenolate ligands.

In the field of catalytic $\alpha$-olefin polymerization, variation in the size of substituents present in the ligands can have large effects. Reports on iron-based catalysts show that bulky groups on the ancillary ligands give rise to the formation of high molecular weight polyethylene [7, 8], whereas, when the steric bulk is small, only oligomers are formed [9].

An interesting feature of the aminophenolate ligand system is that steric bulk can easily be introduced at different positions, viz. 1) at the ortho position (R), 2) on the nitrogen donor-atom ( $\mathrm{R}^{\prime}$ and/or $\left.\mathrm{R}^{\prime \prime}\right)$ and 3 ) on the benzylic carbon atom $\left(\mathrm{R}^{*}\right)$ (see Figure 1). To study the effect of steric bulk at the three different positions on the geometry around the vanadium nucleus, various vanadium(IV) oxo (bis)phenolates have been prepared, in which either $\mathrm{R}, \mathrm{R}^{\prime}, \mathrm{R}^{\prime \prime}$ or $\mathrm{R}^{*}$ has been varied. The parent compound $\left[\mathrm{VO}\left(\mathrm{OC}_{6} \mathrm{H}_{4}\left(\mathrm{CH}_{2} \mathrm{NMe}_{2}\right)-2\right)_{2}\right]$ (1) was used for comparison [6]. For qualitative comparison of the structures we have used the angular structural parameter $\tau$, which is defined in Figure 2 [10]. For an ideal square pyramidal geometry $\tau$ equals zero, whereas for a trigonal bipyramidal geometry $\tau$ is one.

$$
\tau=\frac{(\mathrm{N}-\mathrm{V}-\mathrm{N})-(\mathrm{O}-\mathrm{V}-\mathrm{O})}{60}
$$
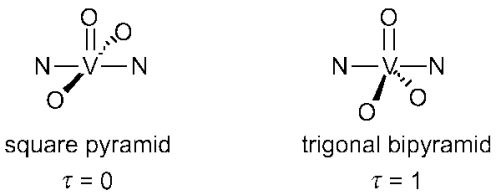

Figure 2 The angular structural parameter $\tau$.

As these vanadium(IV) compounds are paramagnetic, little or no structural information can be obtained from NMR spectroscopy. It is, therefore, of great interest to study whether there is a relation between the electronic parameters which can be obtained, i.e., the hyperfine coupling and the HOMO-LUMO transition, on the one hand and the geometry on the other hand [11]. In order to study a possible relation between EPR and UV/Vis spectroscopic data and the vanadium coordination, several structural features have been investigated. They include the angular structural parameter $\tau$, bond lengths, bond angles and the tetrahedral character of the nitrogen donor atom $\left(\mathrm{THC}_{\mathrm{N}}\right)$. The latter parameter has been introduced for boron-nitrogen adducts to evaluate the $\mathrm{B}-\mathrm{N}$ bond and it is defined [12] as:

$$
\operatorname{THC}_{N}(\%)=\left[1-\frac{\sum_{\mathrm{n}=1}^{6}\left|109.5-\theta_{n}\right|^{\circ}}{90^{\circ}}\right] \times 100
$$

in which $\theta_{1}-\theta_{6}$ are the bond angles around the amino nitrogen atom. $\mathrm{THC}_{\mathrm{N}}$ can vary between 0 and 1 , which represents a trigonal monopyramidal (symmetry $\mathrm{C}_{3 v}$ ) or a tetrahedral geometry (symmetry $T_{d}$ ), respectively. In other words, the non-bonding orbital changes from a pure $\mathrm{p}$-orbital in the case of $\mathrm{THC}_{\mathrm{N}}=0$ to an $\mathrm{sp}^{3}$-orbital for $\mathrm{THC}_{\mathrm{N}}=1$.

\section{Results}

The aminophenols $\mathbf{2}-\mathbf{5}$ were prepared by Mannich reactions from the corresponding phenol with the corresponding secondary amine and formaldehyde in ethanol (Scheme 1) [13].

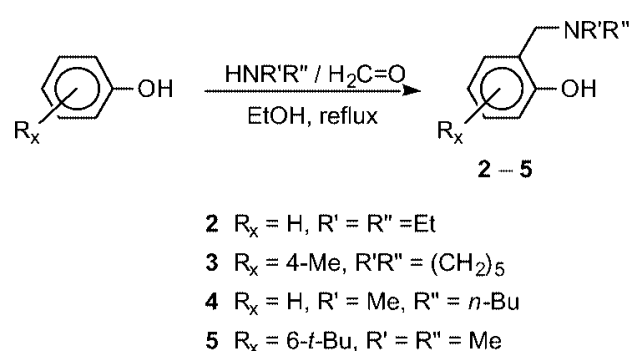

Scheme 1 Synthesis of the aminophenols 2-5.

In order to obtain ortho-aminophenols with substituents on the benzylic position the Mannich reaction sometimes can be used with aldehydes other than formaldehyde. However, the yields are lower [14] and the final result will always be a racemic mixture. In order to solve the latter problem a different route to ortho-aminophenols has been developed, which starts from a benzylic amine and introduces the phenolic function at the ortho position. The benzylic amine, $\mathrm{C}_{6} \mathrm{H}_{5}\left(\mathrm{CH}(\mathrm{Me}) \mathrm{NMe}_{2}\right)$, can be lithiated exclusively at the ortho position with $t$-BuLi in pentane (see Scheme 2) [15]. Following the procedure of Hawthorne [16], the aryllithium compound was reacted with trimethyl borate. After hydrolysis of the boron compound and subsequent oxidation with hydrogen peroxide the enantiomerically pure orthoaminophenols, $(S)-\mathrm{HOC}_{6} \mathrm{H}_{4}\left(\mathrm{CH}(\mathrm{Me}) \mathrm{NMe}_{2}\right)-2(6)$ and $(R)-$ $\mathrm{HOC}_{6} \mathrm{H}_{4}\left(\mathrm{CH}(\mathrm{Me}) \mathrm{NMe}_{2}\right)-2(7)$, were obtained in yields of 72 and $58 \%$, respectively. As the reactions do not affect the chiral carbon atom, it is expected that the configuration at this carbon atom is maintained and this was confirmed by the X-ray crystal structures of the corresponding vanadium compounds (vide infra). 


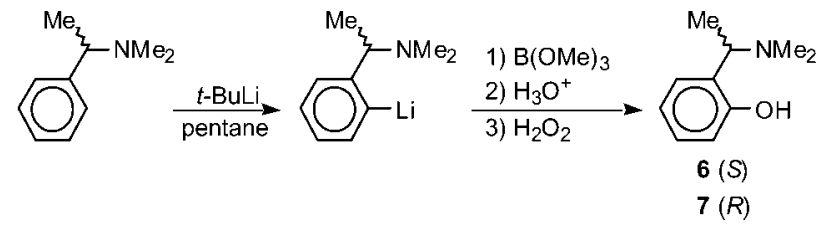

Scheme 2 Synthesis of the aminophenols 6 and 7.

The vanadium oxo (bis)phenolates $\mathbf{8}-\mathbf{1 3}$ were prepared by reacting $\left[\mathrm{VOCl}_{2}(\mathrm{THF})_{2}\right]$ with two equivalents of the corresponding aminophenol in the presence of $\mathrm{Et}_{3} \mathrm{~N}$ (see Scheme 3). They were obtained as blue/purple compounds. The complexes $\mathbf{9 , 1 1}, \mathbf{1 2}$ and $\mathbf{1 3}$ were conveniently crystallized from $\mathrm{Et}_{2} \mathrm{O}$. However, crystallization attempts for $\mathbf{8}$ and $\mathbf{1 0}$ from both apolar solvents such as pentane and $\mathrm{Et}_{2} \mathrm{O}$ and from very polar solvents like $\mathrm{MeNO}_{2}$ and $\mathrm{MeOH}$ were unsuccessful and they were obtained as oils.

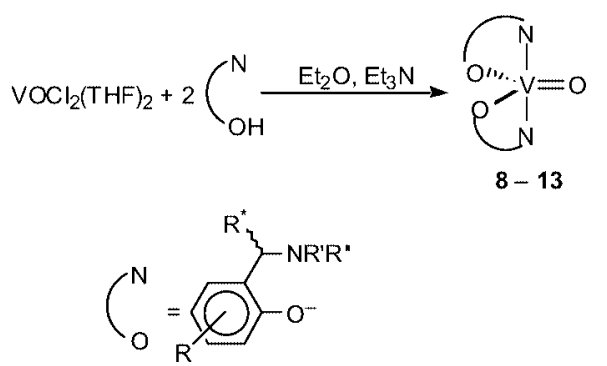

Scheme 3 Synthesis of vanadium(IV) oxo (bis)phenolates 8-13.

\section{Solid state structures of 9,11 and 12}

Crystals of 9, 11, 12 and 13 suitable for X-ray structure determination were obtained from $\mathrm{Et}_{2} \mathrm{O}$ at room temperature $(9,11)$ and $-20^{\circ} \mathrm{C}(12,13)$. Compounds 12 and 13 are enantiomers and the difference in the crystals is just the opposite absolute structure. Only $\mathbf{1 2}$ will be discussed here, as it provided the better data-set. The molecular structures are depicted in Figures 3, 4 and 5. Relevant bond lengths and bond angles are given in Table 1 .

The three structures are quite similar to the structure of the related compound [ $\mathrm{VO}\left(\mathrm{OC}_{6} \mathrm{H}_{4}\left(\mathrm{CH}_{2} \mathrm{NMe}_{2}\right)-2\right]$ (1) [6]. The molecules are approximately $C_{2}$ symmetric and in all four compounds the geometry around the vanadium atom is best described as a distorted trigonal bipyramid with the three oxygen atoms in the equatorial plane and the two nitrogen donor atoms placed at the axial positions. The $\mathrm{V}=$ $\mathrm{O}, \mathrm{V}-\mathrm{O}, \mathrm{V}-\mathrm{N}$ and $\mathrm{O}-\mathrm{C}$ bond lengths are all comparable. Also the $\mathrm{V}-\mathrm{O}-\mathrm{C}$ bond angles as well as the bite-angles of the the aminophenolate ligands have approximately the same value in all four compounds. The difference between the four structures is found in their $\tau$-values. For $\mathbf{1 1}(\tau=$ $0.80)$ this value is much larger than for $\mathbf{1}(\tau=0.59)$, whereas it is smaller in the case of $\mathbf{9}$ and $\mathbf{1 2}(\tau=0.50$ and 0.49 ,
Table 1 Selected bond lengths $/ \AA$ and bond angles $/{ }^{\circ}$ for $\mathbf{9}, \mathbf{1 1}$ and 12.

\begin{tabular}{lccc}
\hline & 9 & 11 & 12 \\
\hline $\mathrm{V} 1-\mathrm{O} 1$ & $1.590(2)$ & $1.598(4)$ & $1.5989(10)$ \\
$\mathrm{V} 1-\mathrm{O} 2$ & $1.883(2)$ & $1.904(4)$ & $1.9040(9)$ \\
$\mathrm{V} 1-\mathrm{O} 3$ & $1.899(2)$ & $1.912(4)$ & $1.8995(10)$ \\
$\mathrm{V} 1-\mathrm{N} 1$ & $2.166(2)$ & $2.151(5)$ & $2.1640(12)$ \\
$\mathrm{V} 1-\mathrm{N} 2$ & $2.165(2)$ & $2.150(6)$ & $2.1695(11)$ \\
$\mathrm{O} 2-\mathrm{C} 1$ & $1.336(3)$ & $1.363(6)$ & $1.3437(16)$ \\
$\mathrm{O} 3-\mathrm{C} 10$ & $1.346(3)$ & & \\
$\mathrm{O} 3-\mathrm{C} 14$ & & $1.348(7)$ & \\
$\mathrm{O} 3-\mathrm{C} 11$ & & & $1.3460(18)$ \\
& & & \\
\hline $\mathrm{O} 1-\mathrm{V} 1-\mathrm{O} 2$ & $114.86(9)$ & $117.79(19)$ & $113.99(5)$ \\
$\mathrm{O} 1-\mathrm{V} 1-\mathrm{O} 3$ & $113.90(9)$ & $116.89(19)$ & $115.22(5)$ \\
$\mathrm{O} 2-\mathrm{V} 1-\mathrm{O} 3$ & $131.20(8)$ & $125.33(18)$ & $130.77(5)$ \\
$\mathrm{V} 1-\mathrm{O} 2-\mathrm{C} 1$ & $134.22(15)$ & $135.0(4)$ & $134.54(8)$ \\
$\mathrm{V} 1-\mathrm{O} 3-\mathrm{C} 10$ & $132.65(15)$ & & \\
$\mathrm{V} 1-\mathrm{O} 3-\mathrm{C} 14$ & & $135.0(4)$ & \\
$\mathrm{V} 1-\mathrm{O} 3-\mathrm{C} 11$ & & & $135.17(9)$ \\
$\mathrm{O} 1-\mathrm{V} 1-\mathrm{N} 1$ & $99.18(8)$ & $93.03(19)$ & $100.37(5)$ \\
$\mathrm{O} 1-\mathrm{V} 1-\mathrm{N} 2$ & $99.30(8)$ & $93.7(2)$ & $99.47(5)$ \\
$\mathrm{N} 1-\mathrm{V} 1-\mathrm{N} 2$ & $161.17(8)$ & $173.3(2)$ & $160.15(5)$ \\
$\mathrm{O} 2-\mathrm{V} 1-\mathrm{N} 1$ & $86.25(8)$ & $87.53(17)$ & $86.87(4)$ \\
$\mathrm{O} 3-\mathrm{V} 1-\mathrm{N} 2$ & $87.85(7)$ & $86.82(19)$ & $86.40(4)$ \\
\hline
\end{tabular}

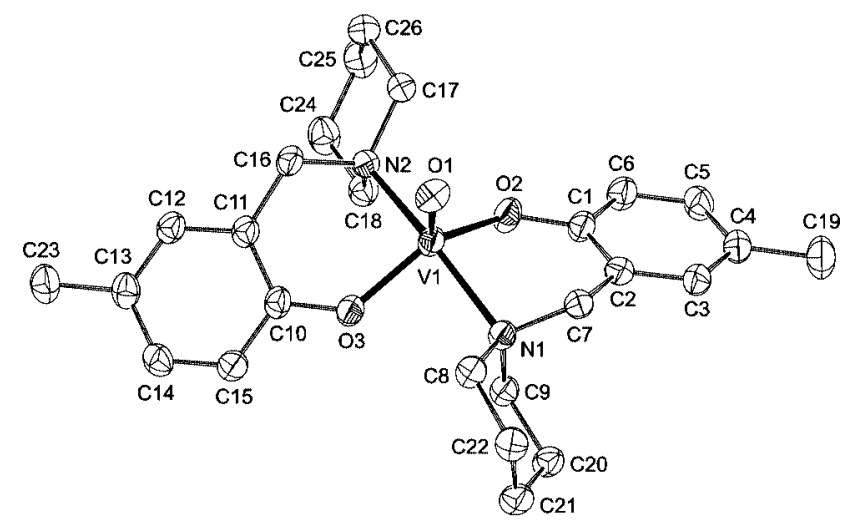

Figure 3 Displacement ellipsoid plot of $\mathbf{9}$, drawn at $50 \%$ probability. Hydrogen atoms are omitted for clarity.

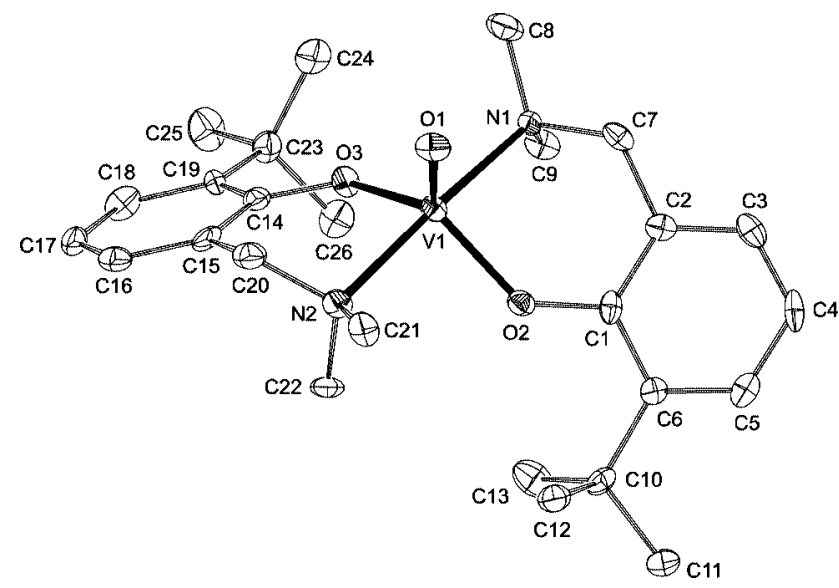

Figure 4 Displacement ellipsoid plot of 11, drawn at $50 \%$ probability. Hydrogen atoms are omitted for clarity. 


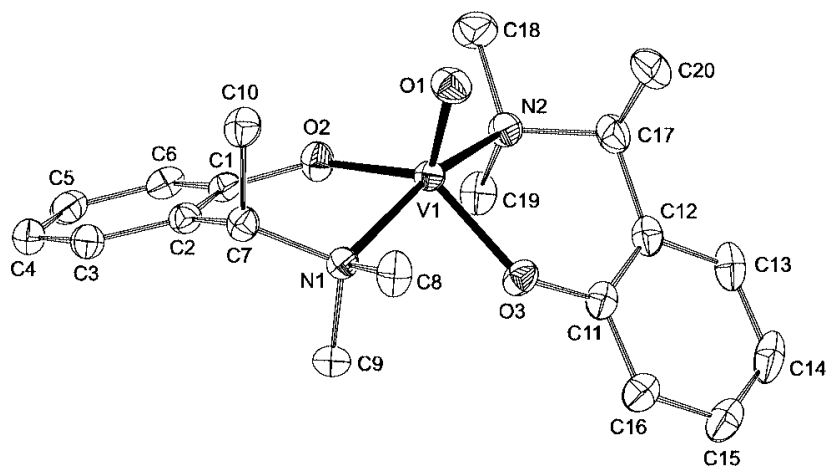

Figure 5 Displacement ellipsoid plot of 12, drawn at $50 \%$ probability. Hydrogen atoms are omitted for clarity.

respectively). Earlier research on the effect of steric bulk in vanadyl complexes with sterically crowded Schiff base ligands showed that increasing the size of the imino-nitrogen substituent or the substituent at the ortho position of the arene ring resulted in an increase of $\tau$ [17]. These results are corroborated by the structure of $\mathbf{1 1}$. However, the introduction of steric bulk at the amino nitrogen atom (9) or at the $\alpha$-carbon (12) resulted in a change in the opposite direction. The reason for this might be the steric interference of these substituents with the oxo oxygen atom, which forces the $\mathrm{O} 1-\mathrm{V}-\mathrm{N}$ angle to open up. This is most apparent in 12, where the methyl groups are in axial positions, resulting in a strong 1,3-diaxial interaction between the methyl and the oxo groups.

\section{EPR analysis}

EPR spectra showed the characteristic octet structure due to the hyperfine interaction of the vanadium nucleus ( $\mathrm{I}=$ $7 / 2$ ) with the unpaired electron. The isotropic $A$ and $g$ values are listed in Table 2. These values show that the effect of geometrical changes on the hyperfine coupling constant (HFC) is relatively large ( $\Delta A_{\text {iso }}=3.2$ Gauss). This delta is remarkable considering that variations of the para-substituents in $\left[\mathrm{VO}\left(\mathrm{OC}_{6} \mathrm{H}_{3}\left(\mathrm{CH}_{2} \mathrm{NMe}_{2}\right)_{2}-\mathrm{R}-4\right)_{2}\right](\mathrm{R}=\mathrm{MeO}, \mathrm{N}=$ $\mathrm{NPh}$ ) gave a $\Delta A_{\text {iso }}$ of only 0.7 Gauss [6]. The $g_{\text {iso }}$ factor is constant within experimental error.

Table 2 Isotropic EPR data for complexes 1, 9, 11 and 12. ${ }^{\text {a) }}$

\begin{tabular}{ccc}
\hline Complex & $A_{\text {iso }}\left(\right.$ Gauss ${ }^{\text {b) }}$ & $g_{\text {iso }}{ }^{\text {c) }}$ \\
\hline $\mathbf{1}$ d) & 100.65 & 1.972 \\
$\mathbf{9}$ & 100.74 & 1.971 \\
$\mathbf{1 1}$ & 97.54 & 1.970 \\
$\mathbf{1 2}$ & 99.71 & 1.971 \\
\hline
\end{tabular}

a) In toluene at room temperature. b) 1 Gauss $=0.932 \times 10^{-4} \mathrm{~cm}^{-1}$; estimated error \pm 0.05 Gauss. ${ }^{c)}$ Estimated error $\pm 0.001{ }^{\text {d) }}$ Ref. [6].
In order to obtain more structural information, frozensolution EPR spectra of 1, 9, 11 and $\mathbf{1 2}$ were measured. The anisotropic $A$ and $g$ values were obtained by spectral simulation [18] and the results are listed in Table 3 (for exemplary frozen state and simulated spectra and a more detailed description of the spectra, see ref. [6]). The spectra of $\mathbf{1}, \mathbf{1 1}$ and $\mathbf{1 2}$ are rhombic with the rhombicity increasing with $\mathrm{THC}_{\mathrm{N}}$. Whereas both $A_{\mathrm{xx}}$ and $A_{\mathrm{zz}}$ display similar behavior, i.e. they decrease with an increase of $\mathrm{THC}_{\mathrm{N}}, A_{\mathrm{yy}}$ does not seem to be related to structural parameters. Interestingly, the nature of the observed rhombicity differs from that of the structurally related vanadyl Schiff bases. In the latter complexes the difference $\left|A_{\mathrm{xx}}-A_{\mathrm{yy}}\right|$ varies between 5.0 and 12.4 Gauss, whereas a constant value for $\left(g_{\mathrm{xx}}-\right.$ $g_{\text {yy }}$ ) of 0.002 is found. For complexes $\mathbf{1}, \mathbf{1 1}$ and $\mathbf{1 2}$ also a difference in $\left|A_{\mathrm{xx}}-A_{\mathrm{yy}}\right|$ is found, although the range is much smaller $(0.3-1.0$ Gauss $)$. Here, $\left(g_{\mathrm{xx}}-g_{\mathrm{yy}}\right)$ is not constant and varies between 0.005 and 0.013 . Preliminary $A b$ Initio calculations on both types of complexes revealed similar results [19]. At this moment we do not know how to explain these observations.

Table 3 Anisotropic $A$ and $g$ values for complexes 1, 9, 11 and 12. ${ }^{\text {a) }}$

\begin{tabular}{lllllll}
\hline Complex & $A_{\text {xx }}$ & $A_{\text {yy }}$ & $A_{\text {zz }}$ & $g_{\mathrm{xx}}$ & $g_{\mathrm{yy}}$ & $g_{\mathrm{zz}}$ \\
\hline $\mathbf{1}$ & 60.1 & 60.4 & 180.5 & 1.985 & 1.977 & 1.9482 \\
$\mathbf{9}$ & 60.0 & 60.0 & 181.0 & 1.985 & 1.977 & 1.9465 \\
$\mathbf{1 1}$ & 58.0 & 59.0 & 179.0 & 1.983 & 1.976 & 1.945 \\
$\mathbf{1 2}$ & 59.4 & 60.6 & 180.0 & 1.980 & 1.9754 & 1.9462 \\
\hline
\end{tabular}

a) In toluene at $150 \mathrm{~K} ; A$ values in Gauss.

It has been shown that $A_{\mathrm{zz}}$ is indicative for the donor type of the "equatorial" ligands [20]. This is reflected in the empirical additivity relationship,

$$
A_{z z, \text { calc }}=\sum_{i} \mathrm{n}_{i} A_{z, i}
$$

in which $\mathrm{n}_{i}$ is the number of ligands of type $i$ and $A_{z, i}$ is the value for the contribution of a ligand of type $i$. As the contribution of a tertiary amine is not known, equation 2 can also be used to calculate this value. Using the average observed value of 179.9 Gauss for $A_{\mathrm{zz}}$ in complexes $\mathbf{1 , 9 , 1 1}$ and 12 and the $A_{\mathrm{z}, i}$ value for a phenolate ligand (41.7 Gauss) the $A_{z, i}$ for a tertiary amine was found to be 48.3 Gauss. This is significantly higher than the value for primary amines (43.0 Gauss), which is consistent with the findings that increase of the basicity of the ligands results in an increase of $A_{\text {iso }}$ [21].

\section{${ }^{14} N$ ESEEM Spectroscopy}

Fukui et al. have reported that the ${ }^{14} \mathrm{~N}$ coupling parameters in vanadium(IV) oxo complexes are related to the $\mathrm{sp}^{\mathrm{n}}$ character of the nitrogen lone-pair [22]. They showed that the absolute value of the isotropic hyperfine coupling constant increases with an increase of the s-character of the 
bond. In complexes 1, 9, 11 and 12 the tetrahedral character of the amine nitrogen varies (see Table 4) and this means that the s-character of the vanadium-nitrogen bond also changes. In order to find out whether this is reflected in the ${ }^{14} \mathrm{~N}$ coupling parameters, Electron Spin Echo Envelope Modulation (ESEEM) spectroscopy has been applied. The values for $A_{\mathrm{zz}}, A_{\mathrm{xx}}$ and $A_{\mathrm{yy}}$ (see Table 4) have been estimated from two- and three-pulse ESEEM spectra taken at the parallel and perpendicular positions in the EPR spectra according to the procedure of Reijerse et al. [23]. The $\left|A_{\text {iso }}\right|$ values of 1, 9, 11 and 12 are lower than those found by Fukui et al. (VO(edda), 4.98 MHz; VO(gly)2, $5.10 \mathrm{MHz}$ ) [22], and the order seems to be determined by the basicity of the nitrogen atoms, i.e. $\mathrm{R}_{3} \mathrm{~N}<\mathrm{R}_{2} \mathrm{HN}<\mathrm{RH}_{2} \mathrm{~N}$.

The differences between the values of $A_{\text {iso }}$ for $\mathbf{1 , 9 , 1 1}$ and 12 are small and almost within experimental error. Unfortunately, there does not appear to be a relation between $A_{\text {iso }}$ and the tetrahedral character of the amino nitrogen atoms. However, it must be noted that the correlation between ${ }^{14} \mathrm{~N}$ coupling parameters and the $\mathrm{sp}^{\mathrm{n}}$ character of the nitrogen lone-pair is based on a nearly constant polarization of the nitrogen lone-pair orbital. Significant geometrical distortions, such as in 12, and/or the presence of electron-donating or -withdrawing ligands appearantly disturb this correlation. Consequently, the ${ }^{14} \mathrm{~N}$ coupling parameters cannot be used to determine geometrical changes.

Table $4{ }^{14} \mathrm{~N}$ hyperfine coupling constants for the complexes $\mathbf{1}, \mathbf{9}$, 11 and 12. ${ }^{\text {a) }}$

\begin{tabular}{llllll}
\hline Complex & $\mathrm{THC}_{\mathrm{N}}$ & $\left|A_{\mathrm{zz}}\right|$ & $\left|A_{\mathrm{xx}}\right|$ & $\left|A_{\mathrm{yy}}\right|$ & $\left|A_{\text {iso }}\right|$ \\
\hline $\mathbf{1}$ & 91.6 & 4.7 & 4.8 & 4.7 & 4.75 \\
$\mathbf{9}$ & 92.6 & 4.85 & 4.7 & 4.6 & 4.7 \\
$\mathbf{1 1}$ & 86.7 & 4.85 & 4.6 & 4.5 & 4.65 \\
$\mathbf{1 2}$ & 89.3 & 4.7 & 4.6 & 4.3 & 4.5
\end{tabular}

a) In toluene at $25 \mathrm{~K} . A$ values in $\mathrm{MHz}$; estimated error $\pm 0.1 \mathrm{MHz}$.

\section{UVIVis spectroscopy}

The parent compound $\mathbf{1}$ as well as the new compounds $\mathbf{9}$, 11 and 12 are blue/purple. UV/Vis analysis of these complexes showed similar spectra (see Table 5), which could be assigned as reported before according to the molecular scheme of $\left[\mathrm{VO}\left(\mathrm{H}_{2} \mathrm{O}\right)_{5}\right][6,24]$. The spectra display a broad absorption around $900 \mathrm{~nm}$, which belongs to $\mathrm{d}_{\mathrm{xy}} \rightarrow \mathrm{d}_{\mathrm{yz}}$ transitions. While the $\mathrm{d}_{\mathrm{xy}} \rightarrow \mathrm{d}_{\mathrm{xz}}$ transition in the other vanadium oxo (bis)phenolates is observed as a shoulder on

Table $5 \mathrm{UV} / \mathrm{Vis}$ data for complexes 1, 9, 11 and 12. ${ }^{\text {a) }}$

\begin{tabular}{lllll}
\hline Complex & $\mathrm{d}_{\mathrm{xy}} \rightarrow \mathrm{d}_{\mathrm{yz}}$ & $\mathrm{d}_{\mathrm{xy}} \rightarrow \mathrm{d}_{\mathrm{xz}}$ & $\mathrm{d}_{\mathrm{xy}} \rightarrow \mathrm{d}_{\mathrm{x}^{2}-\mathrm{y}^{2}}$ & $\mathrm{~d}_{\mathrm{xy}} \rightarrow \mathrm{d}_{\mathrm{z}^{2}}$ \\
\hline $\mathbf{1} \mathbf{1}^{\mathrm{b})}$ & 877 & $\approx 600$ & 541 & 397 \\
$\mathbf{9}$ & 880 & 625 & 541 & 404 \\
$\mathbf{1 1}$ & 919 & $\approx 600$ & 554 & - \\
$\mathbf{1 2}$ & 855 & $\approx 600$ & 544 & 397 \\
\hline
\end{tabular}

a) In toluene at room temperature; values in $\mathrm{nm}$; estimated error $\pm 1 \mathrm{~nm}$. b) $\operatorname{Ref}[6]$. the $d_{x y} \rightarrow d_{x^{2}-y^{2}}$ transition, for 9 the two are separated. The $d_{x y} \rightarrow d_{z^{2}}$ transition for $\mathbf{1 1}$ is not observed and is masked by a strong absorption belonging to a LMCT or $\pi \rightarrow \pi^{*}$ transition.

\section{Discussion}

As vanadium(IV) compounds are paramagnetic, little or no structural information can be obtained from NMR spectroscopy. It is, therefore, of great interest to study whether there is a relation between the electronic parameters which can be obtained, i.e., the hyperfine coupling and the HOMO-LUMO transition, on the one hand and the geometry on the other hand. For the vanadium oxo (bis)phenolate complexes with different substituents on the meta or para position, both $A_{\text {iso }}$ and the HOMO-LUMO transition are linearly related to the Hammett $\sigma$ constant of the substituents. As a consequence both $A_{\text {iso }}$ and the HOMOLUMO transition are linearly related as well. For the complexes with conformational changes caused by sterical influences this is clearly not the case, since for $A_{\text {iso }}$ the order is $\mathbf{1 1}<\mathbf{1 2}<\mathbf{1}<\mathbf{9}$, whereas for the HOMO-LUMO transition the order is $\mathbf{1 1}<\mathbf{9}<\mathbf{1}<\mathbf{1 2}$. Apparently, the values for $A_{\text {iso }}$ and the HOMO-LUMO transition are influenced by different parameters. Although this seems remarkable at first, it is probably not very unusual. The difference in HOMOLUMO transition, $\Delta$ (HOMO-LUMO), between $\mathbf{1 1}$ and $\mathbf{1 2}$ is $64 \mathrm{~nm}$. For the vanadyl complexes with different parasubstituents, $\left[\mathrm{VO}\left(\mathrm{OC}_{6} \mathrm{H}_{3}\left(\mathrm{CH}_{2} \mathrm{NMe}_{2}\right)_{2}-\mathrm{R}-4\right)_{2}\right](\mathrm{R}=\mathrm{MeO}$, $\mathrm{N}=\mathrm{NPh})$, the $\Delta(\mathrm{HOMO}-\mathrm{LUMO})$ is $30 \mathrm{~nm}$ [6], which means that the HOMO-LUMO transition is as sensitive to electronic influences caused by inductive and/or mesomeric effects, as it is to geometrical changes. Since it is not possible to modify the steric requirements of the ligand system without changing the electronic influences, it turns out to be impossible to use the HOMO-LUMO transition for determining geometrical changes.

From literature it is known that $A_{\text {iso }}$ and $g_{\text {iso }}$ are related according to the following expression: [25]

$$
A_{\text {iso }}=-P K-\left(g_{\mathrm{e}}-g_{\text {iso }}\right) P
$$

In this equation $P$ is the direct dipolar term (dipole-dipole interaction of the electron moment and the nuclear moment), $K$ is the Fermi contact term, which is related to the amount of unpaired electron density at the vanadium nucleus and $g_{\mathrm{e}}$ is the spectroscopic splitting factor for a free electron, which equals 2.0023. In the four complexes reported here $g_{\text {iso }}$ has the same value and therefore the difference in $A_{\text {iso }}$ has to be caused by a difference in $K$. $K$ depends on the $\mathrm{d}_{\mathrm{xy}}$-orbital population of the unpaired electron, $\left(\beta_{2}{ }^{*}\right)^{2}$. Lowering of $\left(\beta_{2}{ }^{*}\right)^{2}$ arises from delocalization of the electron onto the ligand. If such a delocalization would take place, this would for certain affect the bonding of the donor atoms to the vanadium atom. With respect to the bonding distances no significant differences were observed between the various X-ray crystal structures. However, if the geo- 


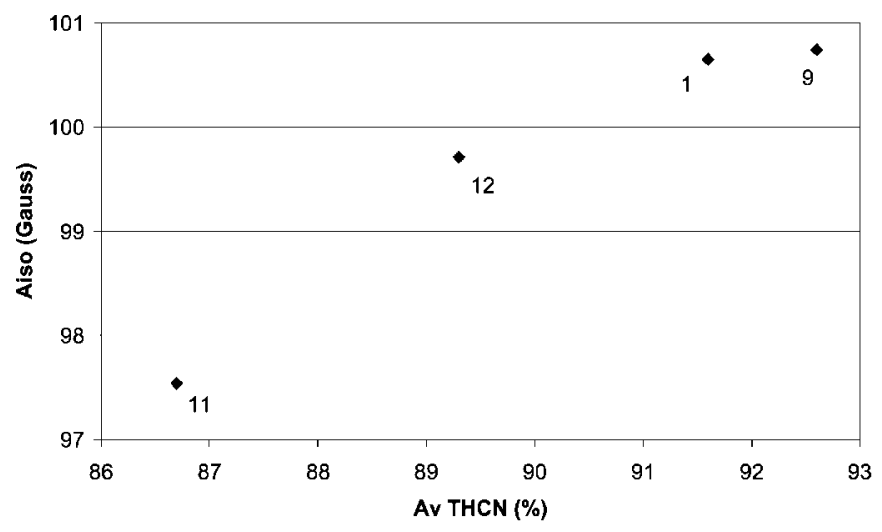

(a)

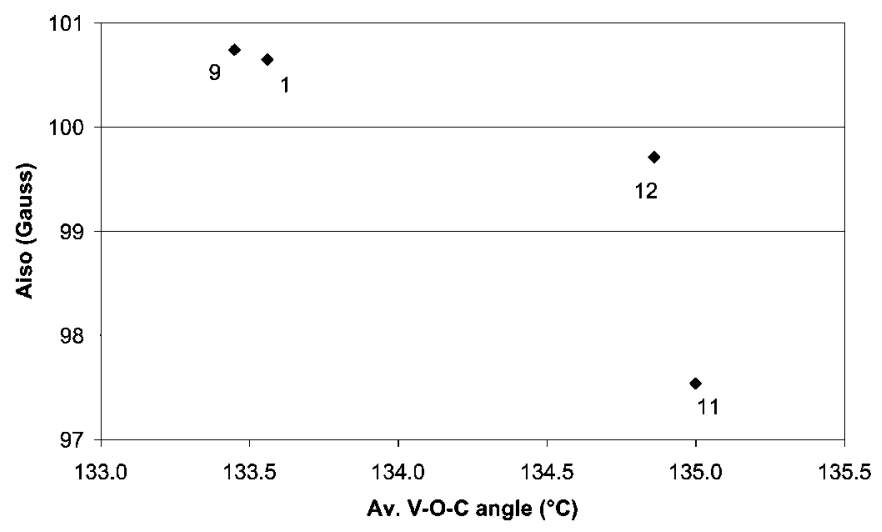

(b)

Figure 6 The isotropic hyperfine coupling, $A_{\text {iso }}$, against the average tetrahedral character of the amino nitrogen atoms, $\mathrm{THC}_{\mathrm{N}}$, (a) and the average $\mathrm{V}-\mathrm{O}-\mathrm{C}$ angle (b) for the complexes $\mathbf{1}, \mathbf{9}, \mathbf{1 1}$ and $\mathbf{1 2}$.

metries around donor atoms, i.e. the $\mathrm{V}-\mathrm{O}-\mathrm{C}$ angle and the $\mathrm{THC}_{\mathrm{N}}$, are considered a clear influence is observed. Plotting $A_{\text {iso }}$ against these two parameters (see Figure 6) shows that $A_{\text {iso }}$ increases with $\mathrm{THC}_{\mathrm{N}}$ and decreases with a rise in the $\mathrm{V}-\mathrm{O}-\mathrm{C}$ angle.

Delocalization of the single electron onto the ligand occurs via an in-plane $\pi$-bonding of the $\mathrm{d}_{\mathrm{xy}}$-orbital with $\mathrm{p}$ orbitals of the ligands. Such an overlap can only occur between the $\mathrm{d}_{\mathrm{xy}}$-orbital and the orbitals of the oxygen atoms, since the amino nitrogen atoms do not have non-bonding orbitals. Both the oxygen atoms have two non-bonding orbitals, i.e. one in the plane of and one perpendicular to the plane of the $\mathrm{d}_{\mathrm{xy}}$-orbital. Obviously, only the former can play a role in the delocalization of the unpaired electron. Increasing the $\mathrm{V}-\mathrm{O}-\mathrm{C}$ angle will make the oxygen atoms of the phenolate ligands more sp-hybridized, which will result in an increase of the p-character of the in-plane lone-pair orbitals and thus improves the $\pi$-bonding to the $\mathrm{d}_{\mathrm{xy}}$-orbital. This view is corroborated by EPR studies on vanadyl imidazole complexes by Pecoraro and co-workers. They showed that the vanadium hyperfine coupling depended on the orientation of the imidazole ligand with respect to the vanadyl unit, i.e., the overlap of the (aromatic) p-orbital of the donating nitrogen atom with the $\mathrm{d}_{\mathrm{xy}}$ orbital [26].

What remains to be answered is whether $\mathrm{THC}_{\mathrm{N}}$ and the $\mathrm{V}-\mathrm{O}-\mathrm{C}$ angle, and thus $A_{\text {iso }}$, are characteristics of the geometry around the vanadium nucleus. In order to answer this question, the values for $\mathrm{THC}_{\mathrm{N}}$ and of the $\mathrm{V}-\mathrm{O}-\mathrm{C}$ angle of the complexes reported here have been plotted versus their $\tau$-values (see Figure 7). For complexes 1, 9, and 11 similar trends are observed in the $\mathrm{THC}_{\mathrm{N}}$ and the $\mathrm{V}-\mathrm{O}-\mathrm{C}$ angle versus $\tau$ plots as in the $A_{\text {iso }}$ versus $\mathrm{THC}_{\mathrm{N}}$ and the $\mathrm{V}-\mathrm{O}-\mathrm{C}$ angle. The position of compound $\mathbf{1 2}$ appears to deviate. Similar behavior is observed for in the $A_{\text {iso }}$ plot versus $\tau$ (see Figure 8). Again the position of 12 seems to be at a too low $\tau$ value. The reason for this discrepancy lies probably in the steric influence, which the methyl group on the $\alpha$-carbon exerts. As observed in the X-ray crystal structure it causes a strong 1,3-diaxial interaction with the oxo group, which forces the $\mathrm{O} 1-\mathrm{V}-\mathrm{N}$ angle to open up. Probably it also influences the dimethylamino functionality, which as a consequence has a different binding to the vanadium nucleus than the one it would have based on the $\tau$ value itself. As the binding of the nitrogen and the oxygen atoms influence the value of $A_{\text {iso }}$, changes in the binding of these atoms caused by anything but the geometry will result in values that are not related to the geometry. This is rather unfortunate, as it means that the EPR $A_{\text {iso }}$ parameter cannot be used to determine geometrical changes.

\section{Conclusions}

In order to study the effect of steric bulk on the vanadium coordination in $O, N$-chelated vanadium oxo (bis)phenolates, six different ortho-aminophenolate ligands have been used. The ortho-aminophenolate system was changed at three different places, i.e. 1) the second ortho position $\left(\mathrm{C}^{6}\right)$ of the arene ring $(\mathrm{R}), 2)$ the substituents at the amino nitrogen $\left(\mathrm{R}^{\prime}\right.$ and $\left.\mathrm{R}^{\prime \prime}\right)$, and 3 ) the benzylic carbon atom $\left(\mathrm{R}^{*}\right)$. The phenols were used in the preparation of the vanadium oxo (bis)phenolate complexes, four of which were structurally characterized, viz., [ $\left.\mathrm{VO}\left(\mathrm{OC}_{6} \mathrm{H}_{3}\left(\mathrm{CH}_{2} \mathrm{~N}\left(\mathrm{CH}_{2}\right)_{5}\right)-2-\mathrm{Me}-4\right)_{2}\right]$ (9), $\left[\mathrm{VO}\left(\mathrm{OC}_{6} \mathrm{H}_{3}\left(\mathrm{CH}_{2} \mathrm{NMe}_{2}\right)-2-t-\mathrm{Bu}-6\right)_{2}\right] \quad(\mathbf{1 1}), \quad[\mathrm{VO}((S)-$ $\left.\left.\mathrm{OC}_{6} \mathrm{H}_{4}\left(\mathrm{CH}(\mathrm{Me}) \mathrm{NMe}_{2}\right)-2\right)_{2}\right](\mathbf{1 2})$ and $\left[\mathrm{VO}\left((R)-\mathrm{OC}_{6} \mathrm{H}_{4}(\mathrm{CH}(-\right.\right.$ $\left.\left.\left.\mathrm{Me}) \mathrm{NMe}_{2}\right)-2\right)_{2}\right](\mathbf{1 3})$. The UV/Vis, solution and frozen state EPR and ${ }^{14} \mathrm{~N}$ ESEEM spectroscopic data of these compounds and those of $\left[\mathrm{VO}\left(\mathrm{C}_{6} \mathrm{H}_{4}\left(\mathrm{CH}_{2} \mathrm{NMe}_{2}\right)-2\right)_{2}\right]$ (1) were measured and attempts were made to correlate them to structural parameters. As characteristics of the vanadium coordination geometry three parameters were used, viz. 1) the angular structural parameter $\tau, 2)$ the tetrahedral character of the nitrogen donor atom $\mathrm{THC}_{\mathrm{N}}$, and 3) the 


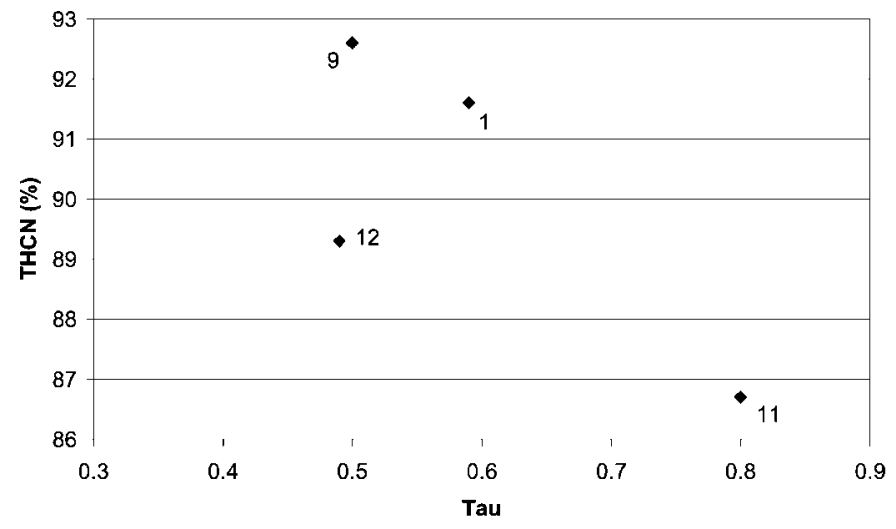

(a)

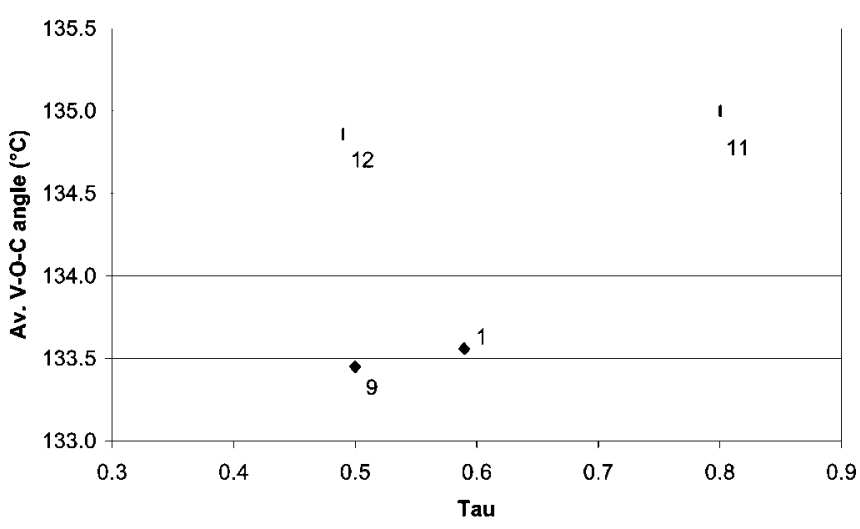

(b)

Figure 7 Average tetrahedral character of the amino nitrogen, $\mathrm{THC}_{\mathrm{N}}$, (a) and the average $\mathrm{V}-\mathrm{O}-\mathrm{C}$ angle (b) against the angular structural parameter $\tau$ for vanadium aminophenolate complexes.

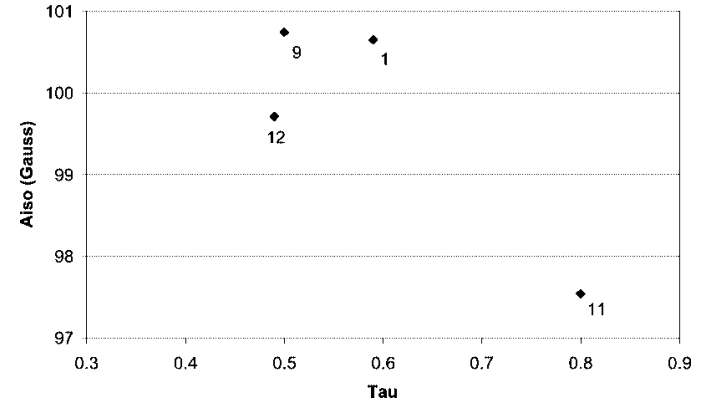

Figure 8 The isotropic hyperfine coupling $A_{\text {iso }}$ versus the angular structural parameter $\tau$ for vanadium aminophenolate complexes.

$\mathrm{V}-\mathrm{O}-\mathrm{C}$ angle. Unfortunately, it turned out that is was not possible to correlate the EPR parameters, the UV/Vis HOMO-LUMO transitions or ${ }^{14} \mathrm{~N}$ hyperfine couplings to the structural parameters.

\section{Experimental Section}

All reactions were performed in an atmosphere of dry, oxygen-free dinitrogen using standard Schlenk techniques. Solvents were carefully dried and distilled prior to use. [ $\left.\mathrm{Li}^{-} \mathrm{C}_{6} \mathrm{H}_{4}\left(\mathrm{CH}(\mathrm{Me}) \mathrm{NMe}_{2}\right)-2\right]$ [15], and [ $\left.\mathrm{VOCl}_{2}(\mathrm{THF})_{2}\right]$ [27] were prepared according to literature procedures. $\mathrm{Et}_{3} \mathrm{~N}$ was distilled from $\mathrm{CaH}_{2} . \mathrm{B}(\mathrm{OMe})_{3}$ was distilled from sodium sand. All other chemicals were obtained from commercial sources and used as received. Elemental analyses were performed by $\mathrm{H}$. Kolbe, Mikroanalytisches Laboratorium, Mülheim, Germany. ${ }^{1} \mathrm{H}$ and ${ }^{13} \mathrm{C}$ NMR spectra were recorded on a Bruker AC300 spectrometer or a Varian Inova 300 spectrometer. Optical rotations were measured on a Perkin-Elmer 241 polarimeter. Solution EPR spectra were recorded on a Bruker ESP 300 spectrometer. ESEEM spectra were recorded at X-band, at $25 \mathrm{~K}$ on a Bruker ESP380 FT-EPR spectrometer employing an overcoupled dielectric resonator. The time resolution was $8 \mathrm{~ns}$ for the two-pulse experi- ments and $16 \mathrm{~ns}$ for the three-pulse experiments. The pulse lengths were set to $16 \mathrm{~ns}$ for a $\pi / 2$ and $24 \mathrm{~ns}$ for a $\pi$ pulse. UV/Vis spectra were recorded on a Cary $5 \mathrm{UV} / \mathrm{Vis}$ spectrophotometer.

\section{Synthesis of the aminophenols.}

The aminophenols $\mathbf{2}-\mathbf{5}$ were prepared by Mannich reactions from the corresponding phenol with the corresponding amine and formaldehyde in ethanol according to literature procedures [13]

$\mathrm{HOC}_{6} \mathrm{H}_{4}\left(\mathrm{CH}_{2} \mathrm{NEt}_{2}\right)-2$ (2).

Colorless liquid. Bp. $85^{\circ} \mathrm{C}, 0.1 \mathrm{~mm} \mathrm{Hg}$.

${ }^{1} \mathrm{H}$ NMR $\left(\mathrm{CDCl}_{3}, 300 \mathrm{MHz}\right): \delta 1.12\left(\mathrm{t}, 6 \mathrm{H},{ }^{3} J_{\mathrm{H}, \mathrm{H}}=7 \mathrm{~Hz}, \mathrm{~N}\left(\mathrm{CH}_{2} \mathrm{CH}_{3}\right)_{2}\right)$, $2.63\left(\mathrm{q}, 4 \mathrm{H},{ }^{3} \mathrm{~J}_{\mathrm{H}, \mathrm{H}}=7 \mathrm{~Hz}, \mathrm{~N}\left(\mathrm{CH}_{2} \mathrm{CH}_{3}\right)_{2}\right), 3.77\left(\mathrm{~s}, 2 \mathrm{H}, \mathrm{CH}_{2}\right), 6.74-6.83(\mathrm{~m}$, $2 \mathrm{H}, \mathrm{Ar}-\mathrm{H}), 6.97$ (m, $1 \mathrm{H}, \mathrm{Ar}-\mathrm{H}), 7.16(\mathrm{~m}, 1 \mathrm{H}, \mathrm{Ar}-\mathrm{H}), 11.41$ (br, $1 \mathrm{H}, \mathrm{OH})$.

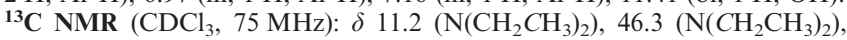
$57.0\left(\mathrm{CH}_{2}\right), 116.1,118.9$ (Ar-C), 122.1 (Ar-C $\left.{ }^{2}\right), 128.3,128.5$ (Ar-C), 158.4 $\left(\mathrm{Ar}-\mathrm{C}^{1}\right)$.

GC-MS: m/z (rel. intensity): 179 (M+1 11$), 164$ (11), 107 (25), 77 (8), 58 (100).

$\mathrm{HOC}_{6} \mathrm{H}_{3}\left(\mathrm{CH}_{2} \mathrm{~N}\left(\mathrm{CH}_{2}\right)_{5}-1,5\right)-2-\mathrm{Me}-4$ (3).

Colorless liquid. Bp. $81-84^{\circ} \mathrm{C}, 0.005 \mathrm{~mm} \mathrm{Hg}$.

${ }^{1} \mathrm{H}$ NMR $\left(\mathrm{CDCl}_{3}, 300 \mathrm{MHz}\right): \delta 1.50$ (br, $2 \mathrm{H}, \mathrm{N}\left(-\mathrm{CH}_{2} \mathrm{CH}_{2} \mathrm{CH}_{2} \mathrm{CH}_{2} \mathrm{CH}_{2}-\right)$ ), 1.63 (pseudo pentet, $4 \mathrm{H}, \mathrm{N}\left(-\mathrm{CH}_{2} \mathrm{CH}_{2} \mathrm{CH}_{2} \mathrm{CH}_{2} \mathrm{CH}_{2}\right.$ )), 2.24 (s, $\left.3 \mathrm{H}, \mathrm{Me}\right), 2.50$ (br, $\left.4 \mathrm{H}, \mathrm{N}\left(-\mathrm{CH}_{2} \mathrm{CH}_{2} \mathrm{CH}_{2} \mathrm{CH}_{2} \mathrm{CH}_{2}-\right)\right), 3,62\left(\mathrm{~s}, 2 \mathrm{H}, \mathrm{CH}_{2}\right), 6.72(\mathrm{~d}, 1 \mathrm{H}$, $\left.{ }^{3} J_{\mathrm{H}, \mathrm{H}}=8 \mathrm{~Hz}, \mathrm{Ar}-\mathrm{H}^{6}\right), 6.76\left(\mathrm{~d}, 1 \mathrm{H},{ }^{4} J_{\mathrm{H}, \mathrm{H}}=2 \mathrm{~Hz}, \mathrm{Ar}-\mathrm{H}^{3}\right), 6.95(\mathrm{dd}, 1 \mathrm{H}$, $\left.{ }^{3} J_{\mathrm{H}, \mathrm{H}}=8 \mathrm{~Hz}, \mathrm{Ar}-\mathrm{H}^{5}\right), 10.60(\mathrm{br}, 1 \mathrm{H}, \mathrm{OH})$.

GC-MS: m/z (rel. intensity): 205 (M+, 31), 188(2), 162(4), 148(3), 121(21), $98(10), 84(100), 56(10)$.

$\mathrm{HOC}_{6} \mathrm{H}_{4}\left(\mathrm{CH}_{2} \mathrm{NMeBu}\right)-2$ (4).

Colorless liquid. Bp. $67-72^{\circ} \mathrm{C}, 0.03 \mathrm{~mm} \mathrm{Hg}$.

${ }^{1} \mathbf{H} \quad$ NMR $\left(\mathrm{CDCl}_{3}, 300 \mathrm{MHz}\right): \quad \delta \quad 0.94\left(\mathrm{t}, 3 \mathrm{H}, \quad{ }^{3} J_{\mathrm{H}}=7.3 \mathrm{~Hz}\right.$, $\mathrm{NCH}_{2} \mathrm{CH}_{2} \mathrm{CH}_{2} \mathrm{CH}_{3}$ ), 1.36 (pseudo sextet, $2 \mathrm{H}, \mathrm{NCH}_{2} \mathrm{CH}_{2} \mathrm{CH}_{2} \mathrm{CH}_{3}$ ), 1.55 (pseudo pentet, $\left.2 \mathrm{H}, \mathrm{NCH}_{2} \mathrm{CH}_{2} \mathrm{CH}_{2} \mathrm{CH}_{3}\right), 2.28(\mathrm{~s}, 3 \mathrm{H}, \mathrm{NMe}), 2.49(\mathrm{t}, 2 \mathrm{H}$, $\left.{ }^{3} J_{\mathrm{H}, \mathrm{H}}=7.3 \mathrm{~Hz}, \mathrm{NCH}_{2} \mathrm{CH}_{2} \mathrm{CH}_{2} \mathrm{CH}_{3}\right), 3.69\left(\mathrm{~s}, 2 \mathrm{H}, \mathrm{CH}_{2}\right), 6.7-6.8(\mathrm{~m}, 2 \mathrm{H}$, Ar-H), 6.9 (m, $1 \mathrm{H}, \mathrm{Ar}-\mathrm{H}), 7.2(\mathrm{~m}, 1 \mathrm{H}, \mathrm{Ar}-\mathrm{H}), 10.99$ (br, $1 \mathrm{H}, \mathrm{OH})$.

GC-MS: $\mathrm{m} / \mathrm{z}$ (rel. intensity): $193\left(\mathrm{M}^{+}, 19\right), 150(98), 136(5), 107(100), 77(31)$.

$\mathrm{HOC}_{6} \mathrm{H}_{3}\left(\mathrm{CH}_{2} \mathrm{NMe}_{2}\right)-2-t$-Bu-6 (5).

Pale pink liquid. Bp. $60{ }^{\circ} \mathrm{C}, 0.005 \mathrm{~mm} \mathrm{Hg}$.

${ }^{1} \mathbf{H}$ NMR $\left(\mathrm{CDCl}_{3}, 300 \mathrm{MHz}\right): \delta 1.44(\mathrm{~s}, 9 \mathrm{H}, t-\mathrm{Bu}), 2.33(\mathrm{~s}, 6 \mathrm{H}, \mathrm{NMe} 2), 3.64$ (s, $\left.2 \mathrm{H}, \mathrm{CH}_{2}\right), 6.73\left(\mathrm{t}, 1 \mathrm{H},{ }^{3} J_{\mathrm{H}, \mathrm{H}}=8 \mathrm{~Hz}, \mathrm{Ar}-\mathrm{H}^{4}\right), 6.85\left(\mathrm{dd}, 1 \mathrm{H},{ }^{3} J_{\mathrm{H}, \mathrm{H}}=\right.$ 
$\left.8 \mathrm{~Hz},{ }^{4} J_{\mathrm{H}, \mathrm{H}}=1 \mathrm{~Hz}, \mathrm{Ar}-\mathrm{H}\right), 7.21\left(\mathrm{dd}, 1 \mathrm{H},{ }^{3} J_{\mathrm{H}, \mathrm{H}}=8 \mathrm{~Hz},{ }^{4} J_{\mathrm{H}, \mathrm{H}}=1 \mathrm{~Hz}, \mathrm{Ar}-\right.$ $\mathrm{H}), 10.8$ (br, $1 \mathrm{H}, \mathrm{OH})$.

${ }^{13} \mathrm{C}$ NMR $\left(\mathrm{CDCl}_{3}, 75 \mathrm{MHz}\right): \delta 29.5\left(\mathrm{C}\left(\mathrm{CH}_{3}\right)_{3}\right), 34.7\left(\mathrm{C}\left(\mathrm{CH}_{3}\right)_{3}\right), 44.2\left(\mathrm{NMe}_{2}\right)$, $63.2\left(\mathrm{CH}_{2}\right), 118.1(\mathrm{Ar}-\mathrm{C}), 122.2\left(\mathrm{Ar}-\mathrm{C}^{2}\right), 125.8,126.5(\mathrm{Ar}-\mathrm{C}), 136.5\left(\mathrm{Ar}-\mathrm{C}^{6}\right)$, 157.1( $\left.\mathrm{Ar}-\mathrm{C}^{1}\right)$.

GC-MS: m/z (rel. intensity): $207\left(\mathrm{M}^{+}, 44\right), 192(22), 164(52), 147(100)$, 119(27), 91(15), 58(14).

Synthesis of $(S)-\mathrm{HOC}_{6} \mathrm{H}_{4}\left(\mathrm{CH}(\mathrm{Me}) \mathrm{NMe}_{2}\right)-2(\mathbf{6})$.

To a stirred solution of $(S)-\left[\mathrm{Li}-\mathrm{C}_{6} \mathrm{H}_{4}\left(\mathrm{CH}(\mathrm{Me}) \mathrm{NMe}_{2}\right)-2\right](2.65 \mathrm{~g}$, $17.1 \mathrm{mmol})$ in $\mathrm{Et}_{2} \mathrm{O}(60 \mathrm{~mL})$ was added $\mathrm{B}(\mathrm{OMe})_{3}(2 \mathrm{~mL}$, $17.5 \mathrm{mmol})$ at $-78^{\circ} \mathrm{C}$. A white precipitate was formed and after warming to room temperature the mixture was stirred for 16 hours. Hydrochloric acid (100 mL, $4 \mathrm{M})$ was added and the resulting biphasic mixture was stirred vigorously for one hour. After separation of the layers the ethereal layer was extracted with hydrochloric acid $(40 \mathrm{~mL}, 4 \mathrm{M})$. The combined aqueous layers were neutralized with $\mathrm{NaHCO}_{3}$ and aqueous $\mathrm{H}_{2} \mathrm{O}_{2}(4.5 \mathrm{~mL}, 35 \% \mathrm{v} / \mathrm{v}$, $52 \mathrm{mmol}$ ) was added. After stirring for one hour the aqueous layer was extracted with $\mathrm{Et}_{2} \mathrm{O}(6 \times 100 \mathrm{~mL})$. The combined ethereal fractions were dried with $\mathrm{MgSO}_{4}$ and the solvent was removed in vacuo. The obtained oil was flash-distilled to give the product as a pale yellow oil (2.04 g; $72 \%)$.

${ }^{1} \mathbf{H}$ NMR $\left(\mathrm{CDCl}_{3}, 300 \mathrm{MHz}\right): \delta 1.39\left(\mathrm{~d}, 3 \mathrm{H},{ }^{3} J_{\mathrm{H}, \mathrm{H}}=7 \mathrm{~Hz}, \alpha-\mathrm{Me}\right), 2.32(\mathrm{~s}$, $\left.6 \mathrm{H}, \mathrm{NMe}_{2}\right), 3.59\left(\mathrm{q}, 1 \mathrm{H},{ }^{3} J_{\mathrm{H}, \mathrm{H}}=7 \mathrm{~Hz}, \mathrm{CH}(\mathrm{Me})\right), 6.79(\mathrm{~m}, 2 \mathrm{H}, \mathrm{Ar}-\mathrm{H})$, $6.98\left(\mathrm{dd}, 1 \mathrm{H},{ }^{3} J_{\mathrm{H}, \mathrm{H}}=7 \mathrm{~Hz},{ }^{4} J_{\mathrm{H}, \mathrm{H}}=1 \mathrm{~Hz}, \operatorname{Ar}-\mathrm{H}\right), 7.14\left(\mathrm{dt}, 1 \mathrm{H},{ }^{3} J_{\mathrm{H}, \mathrm{H}}=\right.$ $\left.8 \mathrm{~Hz},{ }^{4} J_{\mathrm{H}, \mathrm{H}}=1 \mathrm{~Hz}, \mathrm{Ar}-\mathrm{H}\right), 10.45(\mathrm{br}, 1 \mathrm{H}, \mathrm{OH})$.

${ }^{13} \mathrm{C}$ NMR $\left(\mathrm{CDCl}_{3}, 75 \mathrm{MHz}\right): \delta 15.6(\alpha-\mathrm{Me}), 41.6\left(\mathrm{NMe}_{2}\right), 64.8(\mathrm{CH}(\mathrm{Me}))$, 116.4, 118.9, 127.1 (Ar-C), 127.6 (Ar-C $\left.{ }^{2}\right), 128.3$ (Ar-C), $157.4\left(\mathrm{Ar}^{-C^{1}}\right)$. GC-MS: m/z (rel. intensity): $165\left(\mathrm{M}^{+}, 16\right), 150$ (53), 120 (68), 91 (100), 77 (7), 65 (13), 51 (12).

$[\alpha]_{D}:+15.8^{\circ}$ (neat).
Synthesis of $(R)-\mathrm{HOC}_{6} \mathrm{H}_{4}\left(\mathrm{CH}(\mathrm{Me}) \mathrm{NMe}_{2}\right)-2$ (7).

$(R)-\mathrm{HOC}_{6} \mathrm{H}_{4}\left(\mathrm{CH}(\mathrm{Me}) \mathrm{NMe}_{2}\right)-2(7)$ was prepared in a similar way as 6 starting from $(R)-\left[\mathrm{Li}^{-} \mathrm{C}_{6} \mathrm{H}_{4}\left(\mathrm{CH}(\mathrm{Me}) \mathrm{NMe}_{2}\right)-2\right] \quad(4.76 \mathrm{~g}$, $30.7 \mathrm{mmol})$ and was obtained as a colorless oil (2.94 g, $58 \%$ ).

$[\alpha]_{D}:-17.8^{\circ}$ (neat).

General procedure for the synthesis of $\left[\mathrm{V}(=\mathrm{O})(\mathrm{OR})_{2}\right]$.

The vanadyl (bis)phenolates were prepared according to a literature procedure [6] by addition of $\left[\mathrm{VOCl}_{2}(\mathrm{THF})_{2}\right]$ in $\mathrm{Et}_{2} \mathrm{O}$ to an ethereal solution of two equivalents of the phenol and $\mathrm{Et}_{3} \mathrm{~N}$ in $50-100 \%$ excess. The products were purified by crystallization.

[VO $\left.\left(\mathrm{OC}_{6} \mathrm{H}_{3}\left(\mathrm{CH}_{2} \mathrm{~N}\left(\mathrm{CH}_{2}\right)_{5}\right)-2-\mathrm{Me}-4\right)_{2}\right]$ (9).

Crystallized from $\mathrm{Et}_{2} \mathrm{O}$ at $-20^{\circ} \mathrm{C}$. Mp. $179{ }^{\circ} \mathrm{C}$.

Anal. Calc. for $\mathrm{C}_{26} \mathrm{H}_{36} \mathrm{~N}_{2} \mathrm{O}_{3} \mathrm{~V}$ : C, 65.67; H, 7.63; N, 5.89; Found: C, 65.49; H, 7.75; N, $5.91 \%$.

UV/Vis (toluene, $\left.\lambda_{\max }(\mathrm{nm}), \varepsilon\left(\mathrm{M}^{-1} \mathrm{~cm}^{-1}\right)\right): 880,72 ; 625,32 ; 541,44 ; 404,53$. EPR (toluene, $2.3 \mathrm{mM}$ ): $A_{\text {iso }}=100.74 \mathrm{G}, g_{\text {iso }}=1.971$.

$\left[\mathrm{VO}\left(\mathrm{OC}_{6} \mathrm{H}_{3}\left(\mathrm{CH}_{2} \mathrm{NMe}_{2}\right)-2-t-\mathrm{Bu}-6\right)_{2}\right](\mathbf{1 1})$.

Crystallized from $\mathrm{Et}_{2} \mathrm{O}$ at room temperature. Mp. $174{ }^{\circ} \mathrm{C}$.

Anal. Calc. for $\mathrm{C}_{26} \mathrm{H}_{42} \mathrm{~N}_{2} \mathrm{O}_{3} \mathrm{~V}$ : C, 64.85; H, 8.79; N, 5.82; Found: C, 64.74; H, 8.71; N, $5.89 \%$.

UV/Vis (toluene, $\left.\lambda_{\max }(\mathrm{nm}), \varepsilon\left(\mathrm{M}^{-1} \mathrm{~cm}^{-1}\right)\right)$ : 919,$98 ; 554,85$.

EPR (toluene, $2.6 \mathrm{mM}$ ): $A_{\text {iso }}=97.54 \mathrm{G}, g_{\text {iso }}=1.970$.

$\left[\mathrm{VO}\left((S)-\mathrm{OC}_{6} \mathrm{H}_{4}\left(\mathrm{CH}(\mathrm{Me}) \mathrm{NMe}_{2}\right)-2\right)_{2}\right](\mathbf{1 2})$.

Crystallized from $\mathrm{Et}_{2} \mathrm{O}$ at $-20^{\circ} \mathrm{C}$. Mp. $207^{\circ} \mathrm{C}$

Table 6 Crystal data and details on data collection for 9, 11, 12 and $13{ }^{\text {c) }}$

\begin{tabular}{|c|c|c|c|c|}
\hline & 9 & 11 & 12 & 13 \\
\hline Empirical formula & $\mathrm{C}_{26} \mathrm{H}_{36} \mathrm{~N}_{2} \mathrm{O}_{3} \mathrm{~V}$ & $\mathrm{C}_{26} \mathrm{H}_{40} \mathrm{~N}_{2} \mathrm{O}_{3} \mathrm{~V}$ & $\mathrm{C}_{20} \mathrm{H}_{28} \mathrm{~N}_{2} \mathrm{O}_{3} \mathrm{~V}$ & $\mathrm{C}_{20} \mathrm{H}_{28} \mathrm{~N}_{2} \mathrm{O}_{3} \mathrm{~V}$ \\
\hline Formula weight & 475.51 & 479.54 & 395.38 & 395.38 \\
\hline Temperature /K & $150(2)$ & $150(2)$ & $150(2)$ & $150(2)$ \\
\hline Wavelength / & 0.71073 & 0.71073 & 0.71073 & 0.71073 \\
\hline Crystal system & monoclinic & orthorhombic & orthorhombic & orthorhombic \\
\hline Space group & $\mathrm{P} 2{ }_{1} / \mathrm{c}$ (No. 14$)$ & Pbca (No. 61) & $\mathrm{P} 2{ }_{1} 2_{1} 2_{1}$ (No. 19) & $\mathrm{P} 2{ }_{1} 2_{1} 2_{1}$ (No. 19) \\
\hline $\mathrm{a} / \AA$ & $11.053(9)$ & $14.8312(10)$ & $9.1369(1)$ & $9.1270(12)$ \\
\hline $\mathrm{b} / \AA$ & $22.9828(19)$ & $10.6851(10)$ & $9.1600(1)$ & $9.1285(7)$ \\
\hline $\mathrm{c} / \AA$ & $10.3235(15)$ & $32.3936(10)$ & $24.0345(1)$ & $24.015(3)$ \\
\hline$\beta /^{\circ}$ & $114.64(2)$ & 90 & 90 & 90 \\
\hline Volume $/ \AA^{3}$ & $2384(2)$ & $5133.5(6)$ & 2011.54 & $2000.8(4)$ \\
\hline $\mathrm{Z}$ & 4 & 8 & 4 & 4 \\
\hline Calc. density $/\left(\mathrm{g} / \mathrm{cm}^{3}\right)$ & 1.325 & 1.246 & 1.306 & 1.313 \\
\hline$\mu / \mathrm{mm}^{-1}$ & 0.446 & 0.415 & 0.514 & 0.517 \\
\hline Diffractometer & Enraf-Nonius CAD4T & Enraf-Nonius CAD4T & Nonius KappaCCD & Enraf-Nonius CAD4T \\
\hline $\sin (\theta / \lambda)_{\max }$ & 0.648 & 0.603 & 0.648 & 0.648 \\
\hline measured refl. & 21610 & 15113 & 29155 & 5243 \\
\hline unique refl. & 5417 & 4689 & 4475 & 4584 \\
\hline refined param. & 291 & 299 & 347 & 241 \\
\hline Structure solution & DIRDIF-97 & DIRDIF-97 & SHELXS-97 & DIRDIF-97 \\
\hline Crystal size $/ \mathrm{mm}^{3}$ & $0.75 \times 0.30 \times 0.10$ & $0.50 \times 0.20 \times 0.05$ & $0.45 \times 0.41 \times 0.21$ & $0.38 \times 0.20 \times 0.12$ \\
\hline Abs. Correction & None & None & Analytical (PLATON) & DELABS (PLATON) \\
\hline Transmission & - & - & $0.81-0.90$ & $0.44-0.81$ \\
\hline Flack x parameter & - & - & $-0.023(12)$ & $-0.02(4)$ \\
\hline Goodness-of-fit & 1.011 & 0.943 & 1.050 & 0.995 \\
\hline$R 1$ (obs. refl.) $^{\mathrm{a})}$ & 0.0458 & 0.0791 & 0.0226 & 0.0625 \\
\hline$w R 2(\text { all refl. })^{\mathrm{b})}$ & 0.1090 & 0.2667 & 0.0608 & 0.1248 \\
\hline
\end{tabular}

a) $R 1=\Sigma|| F_{\mathrm{o}}|-| F_{\mathrm{c}}|/ \Sigma| F_{\mathrm{o}} \mid$. ${ }^{\text {b) }} w R 2=\left[\Sigma\left[\mathrm{w}\left(F_{\mathrm{o}}{ }^{2}-F_{\mathrm{c}}{ }^{2}\right)^{2}\right] / \Sigma\left[\mathrm{w}\left(F_{\mathrm{o}}{ }^{2}\right)^{2}\right]\right]^{1 / 2}$

c) Crystallographic data for the structure(s) have been deposited with the Cambridge Crystallographic Data Centre. Copies of the data CCDC-140543 (9), 140544 (11), 140545 (12), 140546 13) - can be obtained free of charge on application to The Director, CCDC, 12 Union Road, Cambridge CB2 1EZ, UK (Fax: int.code+(1223)336-033; e-mail for inquiry: fileserv@ccdc.cam.ac.uk; e-mail for deposition: deposit@ccdc.cam.ac.uk). 
Anal. Calc. for $\mathrm{C}_{20} \mathrm{H}_{28} \mathrm{~N}_{2} \mathrm{O}_{3} \mathrm{~V}$ : C, 60.75; H, 7.14; N, 7.09; Found: C, $60.88 ; \mathrm{H}, 7.20 ; \mathrm{N}, 7.12 \%$.

UV/Vis (hexane, $\lambda_{\max }(\mathrm{nm}), \varepsilon\left(\mathrm{M}^{-1} \mathrm{~cm}^{-1}\right)$ ): 848,$54 ; 536,48 ; 397,31$; (toluene, $\left.\lambda_{\max }(\mathrm{nm}), \varepsilon\left(\mathrm{M}^{-1} \mathrm{~cm}^{-1}\right)\right): 855,50 ; 544,47 ; 404,29$.

EPR (hexane, $1.9 \mathrm{mM}$ ): $A_{\text {iso }}=100.28 \mathrm{G}, g_{\text {iso }}=1.971$; (toluene, $2.5 \mathrm{mM}$ ) $A_{\text {iso }}=99.71 \mathrm{G}, g_{\text {iso }}=1.971$.

\section{X-ray Crystallographic Structure Determination and Refinements.}

Dark blue crystals of $\mathbf{9}, \mathbf{1 1}, \mathbf{1 2}$ and $\mathbf{1 3}$ suitable for X-ray diffraction were grown from $\mathrm{Et}_{2} \mathrm{O}$ at room temperature $\left(\mathbf{9}\right.$ and 11) or $-20{ }^{\circ} \mathrm{C}$ (12 and 13). Crystal data and details on data collection are listed in Table 6. Geometrical calculations and illustrations were performed with PLATON [28].

\section{References}

[1] M. P. Hogerheide, M. Wesseling, J. T. B. H. Jastrzebski, J. Boersma, H. Kooijman, A. L. Spek, G. van Koten, Organometallics 1995, 14, 4483.

[2] J. A. M. Brandts, M. D. Janssen, M. P. Hogerheide, J. Boersma, A. L. Spek, G. van Koten, Inorg. Chim. Acta 1999, 291, 326.

[3] P. A. van der Schaaf, E. Wissing, J. Boersma, W. J. J. Smeets, A. L. Spek, G. van Koten, Organometallics 1993, 12, 3624.

[4] a) P. A. van der Schaaf, J. Boersma, W. J. J. Smeets, A. L. Spek, G. van Koten, Inorg. Chem. 1993, 32, 5108. b) P. A. van der Schaaf, R. A. T. M. Abbenhuis, W. P. A. van der Noort, R. de Graaf, D. M. Grove, W. J. J. Smeets, A. L. Spek, G. van Koten, Organometallics 1994, 13, 1433.

[5] J. A. M. Brandts, J. Boersma, A. L. Spek, G. van Koten, Eur. J. Inorg. Chem. 1999, 1727.

[6] H. Hagen, A. Barbon, E. E. van Faassen, B. T. G. Lutz, J. Boersma, A. L. Spek, G. van Koten, Inorg. Chem. 1999, 38, 4079.

[7] G. J. P. Britovsek, V. C. Gibson, B. S. Kimberley, P. J. Maddox, S. J. McTavish, G. A. Solan, A. J. P. White, D. J. Williams, Chem. Commun. 1998, 849.
[8] B. L. Small, M. Brookhart, A. M. A. Bennett, J. Am. Chem. Soc. 1998, 120, 4049.

[9] B. L. Small, M. Brookhart, J. Am. Chem. Soc. 1998, 120, 7143.

[10] A. W. Addison, T. N. Rao, J. Reedijk, J. van Rijn, G. C. Verschoor, J. Chem. Soc., Dalton Trans. 1984, 1349.

[11] A correlation has been reported between the vanadium coordination geometry and the vanadium nuclear quadrupole coupling constant for vandayl Schiff base complexes: C. V. Grant, K. M. Geiser-Bush, C. R. Cornman, R. D. Britt, Inorg. Chem. 1999, 38, 6285.

[12] H. Höpfl, J. Organomet. Chem. 1999, 581, 129.

[13] Methoden der Organische Chemie (Houben-Weyl), 4th ed.; J. Houben, T. Weyl (eds), Georg Thieme Verlag: Stuttgart, Germany, 1957, Vol. 11/1, p 756.

[14] H. Heaney, in Comprehensive Organic Synthesis, B. M. Trost (ed), Pergamon Press: Oxford, U.K., 1991, Vol 2, Chapter 4.2.

[15] D. M. Knotter, H. L. van Maanen, D. M. Grove, A. L. Spek, G. van Koten, Inorg. Chem. 1991, 30, 3309.

[16] M. F. Hawthorne, J. Org. Chem. 1957, 22, 1001.

[17] C. R. Cornman, K. M. Geiser-Bush, S. P. Rowley, P. D. Boyle, Inorg. Chem. 1997, 36, 6401.

[18] Spectral simulations were carried out using the Bruker WINEPR SymFonia program.

[19] E. J. Reijerse, et al., to be published.

[20] N. D. Chasteen, in Biological Magnetic Resonance; L. J. Berliner, J. Reuben (eds), Plenum Press: New York, 1981, Vol 3 , p 53-119.

[21] J. Zah-Letho, E. Samuel, J. Livage, Inorg. Chem. 1988, 27, 2233.

[22] K. Fukui, H. Ohya-Nishiguchi, H. Kamada, Inorg. Chem. 1997, 36, 5518.

[23] E. J. Reijerse, A. M. Tyryshkin. S. A. Dikanov, J. Magn. Reson. 1998, 131, 295.

[24] C. J. Ballhausen, H. B. Gray, Inorg. Chem. 1962, 1, 111.

[25] L. J. Boucher, E. C. Tynan, T. F. Yen, in Electron Spin Resonance of Metal Complexes; T.F. Yen (ed), Adam Hilger Ltd.: London, 1969, p 111-130.

[26] T. S. Smith, C. A. Root, J. W. Kampf, P. G. Rasmussen, V. L. Pecoraro, J. Am. Chem. Soc. 2000, 122, 767.

[27] R. J. Kern, J. Inorg. Nucl. Chem. 1962, 24, 1105.

[28] A. L. Spek, PLATON A multipurpose crystallographic tool; Utrecht University, The Netherlands, 1998. 